\title{
Immobilization of Lead by Phosphate Amended Polonite
}

\author{
Michael A. Butkus ${ }^{\mathrm{a}^{*}}$, Dawn E. Riegner ${ }^{\mathrm{b}}$ and Johannes Olind ${ }^{\mathrm{a}}$
}

a. Environmental Engineering Program, Department of Geography and Environmental

Engineering

b. Chemistry Program, Department of Chemistry and Life Science

U.S. Military Academy, West Point, New York 10996

* corresponding author, (845) 938 -2820 (p), (845) 938 - 3339 (f), Michael.Butkus@usma.edu 


\section{Abstract}

2

3 Polonite is an alkaline material that has been used to remove nutrients from domestic wastewater

4 and it has been evaluated as a fertilizer. Stabilization of $\mathrm{Pb}$ by Polonite and Polonite amended

5 with $\mathrm{PO}_{4}$ (Polonite-P) was studied. Octacalcium phosphate $\left(\mathrm{Ca}_{8} \mathrm{H}_{2}\left(\mathrm{PO}_{4}\right)_{6} \cdot 5 \mathrm{H}_{2} \mathrm{O}\right)$ was a primary

6 species of $\mathrm{PO}_{4}$ formed on the surface of Polonite-P. Lead was found to be associated with

7 pozzolanic reaction products in $\mathrm{Pb}$ treated Polonite and $\mathrm{Pb}$ treated Polonite- $\mathrm{P}$ samples.

8 Formation of $\mathrm{Pb}$ oxides, as precipitates or surface complexes, were substantial constituents of $\mathrm{Pb}$

9 treated Polonite. Dissolution of $\mathrm{Ca}_{8} \mathrm{H}_{2}\left(\mathrm{PO}_{4}\right)_{6} 5 \mathrm{H}_{2} \mathrm{O}$ followed by formation of $\mathrm{Pb}_{4} \mathrm{O}\left(\mathrm{PO}_{4}\right)_{2}$ was a

10 probable mechanism of $\mathrm{Pb}$ removal by Polonite-P. Polonite-P could be a suitable replacement

11 for current $\mathrm{PO}_{4}$ sources as a $\mathrm{Pb}$ stabilization agent. Finally, LDI-TOF was an effective technique

12 for evaluating forms of $\mathrm{Pb}$ on Polonite and Polonite-P.

13

14 Keywords: Polonite, Lead, Phosphate, Stabilization

15

16

17 


\section{Introduction}

Lead contamination of soils and groundwater in the environment is a significant

21 environmental challenge. Lead particles in soil undergo weathering processes, which result in the

22 formation of $\mathrm{Pb}$ oxides and $\mathrm{Pb}$ carbonates (Jørgensen and Willems, 1987). Nriagu (1974)

23 proposed the use of phosphate $\left(\mathrm{PO}_{4}\right)$ to immobilize $\mathrm{Pb}$ in situ via the formation of low solubility

24 pyromorphites and this approach has become an accepted remediation strategy ( $c f$. Chrysochoou

25 et al., 2007). Hydroxyapatite $\left(\mathrm{Ca}_{5}\left(\mathrm{PO}_{4}\right)_{3}(\mathrm{OH})\right.$; hereafter referred to as $\left.\mathrm{HA}\right)$ has been used as a

26 source of $\mathrm{PO}_{4}$ for in situ $\mathrm{Pb}$ immobilization, but is limited by its dissolution rate, especially in the

27 neutral to alkaline $\mathrm{pH}$ range (Hashimoto and Sato, 2007). Similarly, stabilization of $\mathrm{Pb}$ with $\mathrm{PO}_{4}$

28 rock has been limited by dissolution rate (Park et al., 2011). Consequently, the extensive

29 incubation times required by these $\mathrm{PO}_{4}$ sources may not be practical under some field conditions.

30 Soil acidification has been recommended for in situ stabilization of $\mathrm{Pb}$ with $\mathrm{HA}$ to facilitate

31 dissolution of the HA amendment (Suzuki et al., 1984; Hashimoto and Sato, 2007). While some

32 studies have demonstrated that $\mathrm{PO}_{4}$ can retard movement of $\mathrm{Pb}$ in the environment, some forms

33 of $\mathrm{PO}_{4}$ treatment have been reported to increase $\mathrm{Pb}$ concentrations in field water leaching tests

34 (Kilgour et al., 2008; Park et al., 2011). Butkus and Johnson (2011a) reported that transport of

$35 \mathrm{~Pb}$ bearing intermediates formed in the presence of $\mathrm{HA}$ exceeded that of a $\mathrm{Pb}$ control at low $\mathrm{pH}$,

36 which indicates that acidic $\mathrm{pH}$ can be a drawback when attempting to stabilize heavy metals in

37 soil. Phosphoric acid and highly soluble phosphate salts can be used to overcome HA

38 dissolution limitations (Ryan et al., 2004; Butkus and Johnson, 2011a and 2011b), but cultural

39 eutrophication concerns are a significant detriment ( $c f$. Park et al., 2011). Although some non- 
40 apatite forms of calcium phosphates have demonstrated a greater $\mathrm{Pb}$ stabilization efficacy ( $c f$.

41 Sugiyama et al., 2002), an ideal phosphate amendment to immobilize $\mathrm{Pb}$ has yet to be identified.

Polonite (trade mark Polonite $\left.{ }^{\circledR}\right)$ is a substance that results from heating $\left(900{ }^{\circ} \mathrm{C}\right)$ Opoka,

45 a naturally occurring sedimentary rock (Renman and Renman, 2010). Opoka is mainly

46 comprised of $\mathrm{SiO}_{2}$ and $\mathrm{CaCO}_{3}$ and heating converts some $\mathrm{CaCO}_{3}$ to reactive $\mathrm{CaO}$ (Renman and

47 Renman, 2010). Renman et al. (2009) reported that Polonite is primarily comprised of the

48 following compounds: $\mathrm{SiO}_{2}(45 \%) ; \mathrm{CaO}(45 \%) ; \mathrm{Al}_{2} \mathrm{O}_{3}(4 \%) ; \mathrm{Fe}_{2} \mathrm{O}_{3}(2 \%)$; and, $\mathrm{K}_{2} \mathrm{O}(1 \%)$.

49 Recently, Kolosov (2014) reported that Polonite contains substantial amounts of $\mathrm{CaCO}_{3}$. The

50 incongruity between these reports has not been resolved. Cucarell et al. (2009) reported that

51 untreated Polonite contains $0.4 \mathrm{~g} \mathrm{P} / \mathrm{kg}$ Polonite. Due to the $\mathrm{PO}_{4}$ sorption capacity of Polonite, it

52 has been considered for use as substrate for wastewater nutrient removal (Renman and Renman,

53 2010). Polonite has also been evaluated as a multicomponent fertilizer (Cucarella et al, 2008)

54 and for treating landfill leachate (Kietlińska and Renman, 2005). Kietlińska and Renman (2005)

55 reported that Polonite had 99\%, 93\%, 86\%, and 67\% removal efficiencies for $\mathrm{Mn}, \mathrm{Fe}, \mathrm{Zn}$, and

$56 \mathrm{Cu}$, respectively in column leaching tests. Therefore, it was hypothesized that Polonite could be

57 used for stabilization of $\mathrm{Pb}$. Further, it was hypothesized that $\mathrm{PO}_{4}$ amended Polonite (Polonite-

$58 \mathrm{P})$ could serve as $\mathrm{PO}_{4}$ source for $\mathrm{Pb}$ stabilization via formation of $\mathrm{Pb}-\mathrm{PO}_{4}$ precipitates and

59 overcome the limitations of other $\mathrm{PO}_{4}$ sources, including those described above. These

60 hypotheses were tested by evaluation of the speciation of $\mathrm{Pb}$ in aqueous systems comprised of

61 Polonite and Polonite-P. The effectiveness of laser desorption ionization mass spectrometry with 
62 time of flight detection (LDI-TOF), as a tool for evaluating inorganic surface speciation, was

63 also evaluated.

64

65

66 
Polonite, Bioptech (Sigtuna, Sweden) was received as dry media with a size range of $c a$.

$72 \quad$ 2-6 mm. Polonite-P was prepared as follows. Four grams of Polonite were combined with a 16

$73 \mathrm{~mL}$ solution comprised of $1010 \mathrm{mg} \mathrm{KNO}_{3} / \mathrm{L}$, Fisher Scientific (Fair Lawn, NJ), and $7320 \mathrm{mg}$

$74 \mathrm{~K}_{2} \mathrm{HPO}_{4} / \mathrm{L}$, Fisher Scientific (Fair Lawn, NJ). The $\mathrm{PO}_{4}$ concentration was based on $\mathrm{PO}_{4}$

75 adsorption capacity ( $15 \mathrm{mg} \mathrm{PO}_{4} / \mathrm{g}$ Polonite) that was measured for Polonite (data not shown),

76 which is comparable to values reported in the literature (Herrmann et al., 2014). The resulting

77 suspensions were incubated under constant shaking, $200 \mathrm{RPM}$, at $25^{\circ} \mathrm{C}$ for 48 hours. This

78 incubation time was based on kinetics studies, which revealed that equilibrium was achieved in

$79 \mathrm{ca} .18 \mathrm{hrs}$ and it is consistent with other studies using similar solid to liquid ratios and sorbents

80 (cf. Cucarella and Renman, 2009). Following incubation, the suspensions were washed with

$811010 \mathrm{mg} \mathrm{KNO}_{3} / \mathrm{L}$, dried, and stored.

\section{$83 \quad 2.2$ Sorption experiments}

84

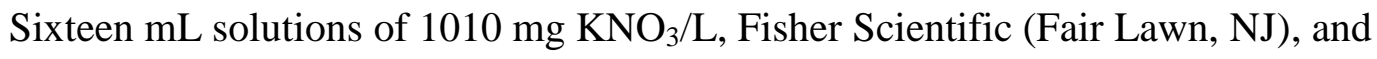
$\mathrm{Pb}\left(\mathrm{NO}_{3}\right)_{2}$, Fisher Scientific (Fair Lawn, NJ), with initial concentrations ranging from $1 \mathrm{mg} \mathrm{Pb} / \mathrm{L}$ to $10 \times 10^{3} \mathrm{mg} \mathrm{Pb} / \mathrm{L}$ were prepared on the day of the experiment. These $16 \mathrm{~mL}$ solutions were combined with ca. $4 \mathrm{~g}$ of Polonite or $c a .4 \mathrm{~g}$ of Polonite-P. (In each sample, the mass of sorbent was recorded with a precision of 1/10,000 of a gram and subsequently used in sorption 
90 calculations.) The $\mathrm{pH}$ of each sample was measured following 20 minutes of reaction time at

91 room temperature. The resulting suspensions were incubated under constant shaking, 200 RPM,

92 at $25{ }^{\circ} \mathrm{C}$ for 48 hours, which is longer than the typical incubation time of 24 hours for similar

93 studies (cf. Elzinga and Sparks, 2002; Cao et al., 2004; Hashimoto and Sato, 2007; Yin et al.,

94 2013). Following incubation, $\mathrm{pH}$ was measured and then $10 \mathrm{~mL}$ aliquots of the suspension were

95 filtered through $0.45 \mu \mathrm{m}$ Millipore nylon filters (Bedford, MA). Eighty micro-liters of $16 \mathrm{~N}$

$96 \mathrm{HNO}_{3}$ was added to the filtrate, which was then analyzed for $\mathrm{Pb}, \mathrm{P}$, and $\mathrm{Ca}$. Stock $\mathrm{Pb}$

97 suspensions were also combined with $80 \mu \mathrm{L}$ of $16 N \mathrm{HNO}_{3}$ prior to $\mathrm{Pb}$ analysis.

Lead, $\mathrm{Ca}$, and $\mathrm{P}$ concentration were quantified using inductively coupled plasma optical emission spectrometry, ICP-OES, (Optima 2100DV, PerkinElmer, Shelton, CT). Continued

101 calibration verification (CCV) was conducted with a midrange standard: $1.00 \mathrm{mg} \mathrm{Pb} / \mathrm{L}, 1.00 \mathrm{mg}$

$102 \mathrm{Ca} / \mathrm{L}$ and $4.89 \mathrm{mg} \mathrm{P} / \mathrm{L}$. The detection limits for ICP-OES were $0.003 \mathrm{mg} \mathrm{Pb} / \mathrm{L}, 0.03 \mathrm{mg} \mathrm{Ca} / \mathrm{L}$, 103 and $0.05 \mathrm{mg}$ P/L.

\subsection{LDI-TOF}

106

Polonite was ground to power with a mortar and pestle and used as a sorbent as described

108 above and then subsequently analyzed by LDI-TOF. LDI was performed on the samples using a

$10950 \mathrm{~Hz} \mathrm{~N}$ laser $(\lambda=337 \mathrm{~nm})$ source with TOF detection, Shimadzu Axima Confidence (Shimadzu

110 Biotech, Kratos Analytical Limited, Manchester,UK). Samples were prepared for analysis by

111 first suspending them in methanol and then loading them onto a 384-sample-well stainless steel

112 plate, which had been previously acid washed, rinsed with DI water, rinsed with methanol and 113 allowed to air dry in a controlled atmosphere. One micro-liter of suspended sample was 
114 deposited on the plate and solvent was allowed to evaporate. The plate was then loaded into the

115 mass spectrometer. Laser power was optimized by observing signal intensity. At lower laser

116 intensities, the samples are considered to be desorbed and ionized; and, at higher laser intensities

117 they are considered to be ablated or evaporated. Due to the inherent variability in shot to shot

118 spectra, most of the reported spectra are averages of more than 100 profiles, which are co-added

119 spectra from at least 10 laser shots. For both positive and negative ion spectra, the reflectron

120 mode was chosen in order to ensure high enough resolution in the isotopic patterns of the ions of

121 interest. An HA control was prepared in $500 \mathrm{~mL}$ of deionized (DI) water by combining $0.800 \mathrm{~g}$

$122 \mathrm{~Pb}\left(\mathrm{NO}_{3}\right)_{2}$ (Fisher Scientific, Fair Lawn, $\mathrm{NJ}$ ) with $0.480 \mathrm{~g} \mathrm{Na}_{2} \mathrm{HPO}_{4}$ (Fisher Scientific, Fair Lawn,

$123 \mathrm{NJ}$ ) as described by Butkus and Johnson (2011a).

124

125

2.4 SEM -EDS

126

127 Powder samples, described above, were analyzed by SEM-EDS. Analyses were

128 performed on the samples using a Hitachi TM3000 Tabletop Microscope (Hitachi High

129 Technologies America, INC. Dallas, TX) with EDS Quantax70 detector by Bruker (Bruker

130 NanoGmbH, Berlin, Germany). Powdered solid samples were loaded onto a sample stage and

131 placed on a mount for introduction into the vacuum chamber of the SEM. Images were made at

132 various magnifications as indicated in the results.

133

$134 \quad 2.5$ Electrophoresis

135 
137 A suspension was prepared by combining $0.05 \mathrm{~g}$ of powder sample with $30 \mathrm{~mL}$ of $1010 \mathrm{mg}$

$138 \mathrm{KNO}_{3} / \mathrm{L}$, Aldrich, (St. Louis, MO). Electrophoretic mobility of each suspension was analyzed

139 with a Brookhaven Instruments Corp. (Holtsville, NY) Zeta PALS particle analyzer.

140 Electrophoretic mobility was quantified with multiple aliquots from each suspension in order to 141 minimize the effect of sample heterogeneity. 


\section{3. Results}

Trends in $\mathrm{pH}$ at the start and completion of sorption experiments are presented in Figure

147 1. Initial $\mathrm{pH}$ was measured approximately 20 minutes after the acidic $\mathrm{PbNO}_{3}$ solutions were 148 combined with both forms of Polonite and final $\mathrm{pH}$ was measured after the 48 hour incubation

149 period. An increase in $\mathrm{pH}$ was observed in all cases. The alkalinity of the Polonite was greater 150 than the alkalinity of the Polonite-P as indicated by the higher final $\mathrm{pH}$ values of the former.

151 There appeared to be minimal buffering in the circumneutral $\mathrm{pH}$ range (indicated by the gap in $152 \mathrm{pH}$ measurements) for both forms of Polonite following the initial 20 minute reaction period.

153 However, final $\mathrm{pH}$ values were more evenly distributed. Lead uptake as a function of $\mathrm{pH}$ for

154 Polonite and Polonite-P is presented in Figure 2. Trends in the figures are comparable and both 155 show a decrease in $\mathrm{pH}$ with higher $\mathrm{Pb}$ loadings.

Calcium release to solution as function of $\mathrm{Pb}$ removal from solution is presented in

158 Figure 3(a). The axes are presented in logarithmic form to highlight data trends, which are

159 different for each form of Polonite. More Ca was released from the Polonite suspensions at low

$160 \mathrm{~Pb}$ concentrations than for Polonite-P. In addition, the slope in both data sets changed at a $\mathrm{Pb}$

161 removal of approximately 8-10 $\mu$ moles. The linear regions ( $c f$. coefficient of determination

162 values) of Ca release to solution as function of $\mathrm{Pb}$ removal from solution is presented in Figure $1633(b)$.

164

166 Polonite samples at a laser power (LP) of 90. A blank spectrum of the ions formed from the 
167 stainless steel sample holder, which contribute to the overall ion population is presented in

168 Figure 4 (red). A spectrum of Polonite (Figure 4 (blue)) depicts the complexity of this substrate

169 via the variety of ions that were measured. This result was expected based on the composition of

170 Polonite (Gustafsson et al., 2008). Figures 4 (green) and (orange) present spectra for Polonite-P,

171 and $\mathrm{Pb}$ treated Polonite-P (3.97 mg Pb/g Polonite-P). Background peaks generated from the

172 stainless steel are present in all four spectra. The $\mathrm{m} / \mathrm{z}$ data and comparison of the isotopic peak

173 patterns in the spectra with that calculated by the Isotope Distribution Calculator and Mass Spec

174 Plotter (http://www.sisweb.com/mstools/isotope.htm) were used to propose the identity of ions

175 of selected species associated with $\mathrm{Ca}, \mathrm{Pb}, \mathrm{PO}_{4}$, and $\mathrm{Si}$, from each sample (Table 1). The extent

176 to which an ion was observed was defined as follows: small peak ( $\mathrm{sm}$ ) being a minimum of $3 \mathrm{x}$

177 the intensity of the background noise signal and average peak $(\mathrm{X})$ being a minimum of 10x the

178 intensity of the background noise signal. A sample of $\mathrm{Pb}$ treated Polonite at low $\mathrm{Pb}$

179 concentration $\left(3.29 \times 10^{-2} \mathrm{mg} \mathrm{Pb} / \mathrm{g}\right.$ Polonite) was also evaluated, but was not included in Table 1

180 because $\mathrm{Pb}$ species were not detected. The $\mathrm{Pb}$ treated Polonite-P reveals an isotopic cluster of

181 peaks at $\mathrm{m} / \mathrm{z}$ of 509 , which indicates the presence of $\mathrm{Pb}_{2} \mathrm{PO}_{4}$. Additional data collected at

182 slightly higher laser power $(\mathrm{LP}=100)$ resulted in an additional isotopic clusters at $\mathrm{m} / \mathrm{z}$ of 733 and

183 1036, which indicate the presence of $\mathrm{Pb}_{3} \mathrm{O}\left(\mathrm{PO}_{4}\right)$ and $\mathrm{Pb}_{4} \mathrm{O}\left(\mathrm{PO}_{4}\right)_{2}$, respectively. The increase in

184 laser power was necessary to ionize sample components with higher molecular weights.

185 Calcium carbonate was observed in negative mode on all surfaces, with larger peaks detected on

186 Polonite and $\mathrm{Pb}$ treated Polonite-P. However, species containing both $\mathrm{Pb}$ and $\mathrm{CO}_{3}$, e.g. cerussite, 187 were not detected. 
SEM-EDS images of $\mathrm{Pb}$ treated Polonite and $\mathrm{Pb}$ treated Polonite-P are presented in

191 Figure 5. Lead was concentrated in regions where Ca was concentrated on Polonite (Figure

192 5(a)). Lead was not observed in regions where Si was predominant on Polonite. Phosphorus

193 was concentrated in regions where Ca was present on Polonite-P (Figure 5(b)). Lead was highly

194 concentrated in regions where $\mathrm{P}$ was highly concentrated on Polonite-P.

195

Electrophoretic mobility was used to evaluate macroscopic changes on the Polonite and

198 Polonite-P surfaces in the alkaline $\mathrm{pH}$ range (Figure 6). Electrophoretic mobility of Polonite-P

199 was significantly greater than Polonite $(\mathrm{P}<0.025)$. A single factor ANOVA test revealed that

200 electrophoretic mobility of $\mathrm{Pb}$ treated Polonite $\left(3.9 \times 10^{-3} \mathrm{mg} \mathrm{Pb} / \mathrm{g}\right.$ Polonite, $4.0 \mathrm{mg} \mathrm{Pb} / \mathrm{g}$ Polonite,

$20139 \mathrm{mg} \mathrm{Pb} / \mathrm{g}$ Polonite) were not statistically different $(\mathrm{P}<0.29)$, which implies that the charged

202 fraction of Polonite surfaces were mostly unaltered by $\mathrm{Pb}$. However, electrophoretic mobility of

$203 \mathrm{~Pb}$ treated Polonite-P (3.97 g Pb/kg Polonite-P) was significantly higher than Polonite-P (P <

$\left.2041.49 \times 10^{-2}\right)$. Electrophoretic mobility of $\mathrm{PbCO}_{3}$ and $\mathrm{Pb}(\mathrm{OH})_{2}$ were also were significantly

205 different $\left(\mathrm{P}<3.35 \times 10^{-3}\right.$ and $\left.\mathrm{P}<4.52 \times 10^{-4}\right)$ than $\mathrm{Pb}$ treated Polonite $(4.0 \mathrm{~g} \mathrm{~Pb} / \mathrm{kg}$ Polonite $)$ and

206 significantly different $\left(\mathrm{P}<2.44 \times 10^{-4}\right.$ and $\left.\mathrm{P}<3.31 \times 10^{-3}\right)$ than $\mathrm{Pb}$ treated Polonite-P $(4.0 \mathrm{~g} \mathrm{~Pb} / \mathrm{kg}$

207 Polonite-P).

208

209 


\section{Discussion}

211

\subsection{LDI-TOF}

213

214 Literature studies reveal few distinct analyses of inorganic compounds via laser

215 desorption ionization mass spectrometry. The use of LDI-TOF analysis for investigating

216 speciation of inorganic compounds, such as $\mathrm{Pb}$, on complex media including soils and minerals

217 has not been reported. Research is being done to establish a database of inorganic compounds in

218 solids as a generalized approach to predict the species mass spectral behavior (Van Hamm, et al.,

219 2004). In another study, laser microprobe mass analysis (LAMMA), which is a similar

220 technique, was utilized to discriminate between adsorbed and co-precipitated $\mathrm{Pb}$ on individual

221 calcite particles (Wouters et al., 1988). The authors concluded that the method of LAMMA was

222 useful in determining the differences in $\mathrm{Pb}$ distribution at $100 \mathrm{mg} / \mathrm{L}$ and $1000 \mathrm{mg} / \mathrm{L}$. The

223 objective of LDI-TOF, in this work, was to aid in characterization of $\mathrm{Pb}$ and $\mathrm{PO}_{4}$ precipitates and

224 surface complexes on Polonite and Polonite-P surfaces. Analysis using LDI hinges on being able

225 to optimize the laser power intensity to render sample ions that represent sample content and not

226 gas phase ion-ion or ion-neutral interactions. Careful determination of the optimum laser power

227 was carried out to enhance the production of intact molecular ions of interest. Dyson et al. (2004)

228 recommended using a laser power intensity that is just above the threshold for ion production.

229 Consequently, laser power was optimized using this recommendation. The results in Figure 4

230 and Table 1 demonstrate that LDI-TOF can be an effective tool for aiding in characterization of

231 speciation on surfaces that are primarily inorganic. 
237 from dissolution of $\mathrm{CaO}\left(\mathrm{Ca}(\mathrm{OH})_{2}\right.$ when exposed to $\left.\mathrm{H}_{2} \mathrm{O}\right)$, wallastonite $\left(\mathrm{CaSiO}_{3}\right)$, silicates, and

$238 \mathrm{CaCO}_{3}$ because these compounds have been reported to be present in Polonite (Renman et al.,

239 2009; Kolosov, 2014) and similar ionic species were present in the LDI-TOF data (Table 1).

240 Dissolution of $\mathrm{CaSiO}_{3}$ can neutralize acid and increase $\mathrm{Ca}$ as follows ( $c f$. Fernández-Caliani et

241 al., 2008).

$\mathrm{CaSiO}_{3}+2 \mathrm{H}_{2} \mathrm{O}=\mathrm{Ca}^{2+}+2 \mathrm{OH}^{-}+\mathrm{H}_{2} \mathrm{SiO}_{3}$

245 Dissolution of $\mathrm{CaCO}_{3}$ likely influenced $\mathrm{pH}$ and $\mathrm{Ca}$ because the final $\mathrm{pH}$ was near the $\mathrm{pK}_{\mathrm{a} 2}$ of

24610.3 for the carbonate system and Polonite has been reported to contain substantial amounts of

$247 \mathrm{CaCO}_{3}($ Kolosov, 2014).

\subsection{Polonite amended with $\mathrm{PO}_{4}$ (Polonite-P)}


254 was exposed to wastewater containing $\mathrm{PO}_{4}$ at $\mathrm{pH}$ 6.8, the following species were found: $14 \%$

255 amorphous calcium phosphate, $(\mathrm{ACP}) ; 31 \%$ octacalcium phosphate $\left(\mathrm{Ca}_{8} \mathrm{H}_{2}\left(\mathrm{PO}_{4}\right)_{6} 5 \mathrm{H}_{2} \mathrm{O}\right)$; and

$25625 \% \mathrm{HA}$. They also reported that Polonite, used to remediate $\mathrm{PO}_{4}$ in field samples $(150 \mathrm{mg}$

$\left.257 \mathrm{BOD}_{7} / \mathrm{L}, \mathrm{pH} 7.8\right)$, had the following composition: $0 \mathrm{ACP} ; 61 \% \mathrm{Ca}_{8} \mathrm{H}_{2}\left(\mathrm{PO}_{4}\right)_{6}{ }^{\circ} \mathrm{H}_{2} \mathrm{O}$; and $30 \% \mathrm{HA}$

258 (Eveborn et al., 2009). Both of these systems had considerable fractions of $\mathrm{Ca}_{8} \mathrm{H}_{2}\left(\mathrm{PO}_{4}\right)_{6}{ }^{\circ} 5 \mathrm{H}_{2} \mathrm{O}$.

259 More than one form of precipitated $\mathrm{PO}_{4}$ was expected in the Polonite-P systems studied here due

260 to the array of ions present (Wang and Nancollas, 2008). The SEM-EDS images of Polonite-P

261 (Figure 5(b)) indicate that $\mathrm{PO}_{4}$ was found in regions, where Ca was present, which supports the

262 formation of $\mathrm{Ca}_{8} \mathrm{H}_{2}\left(\mathrm{PO}_{4}\right)_{6} 5 \mathrm{H}_{2} \mathrm{O}$ and other $\mathrm{Ca}-\mathrm{PO}_{4}$ precipitates. Reaction of phosphate with

263 Polonite resulted in an increase of $\mathrm{pH}$ from $c a$. 9.6 to $c a$. 11.8. Based on this observation, $\mathrm{PO}_{4}$

264 precipitates may have formed from dissolution of $\mathrm{Ca}(\mathrm{OH})_{2}$ (Yin et al., 2013). Because Eveborn

265 et al. (2009) reported significant concentrations of $\mathrm{Ca}_{8} \mathrm{H}_{2}\left(\mathrm{PO}_{4}\right)_{6} 5 \mathrm{H}_{2} \mathrm{O}$ on Polonite in two distinct

266 systems and considering the observation that $\mathrm{Ca}_{8} \mathrm{H}_{2}\left(\mathrm{PO}_{4}\right)_{6} 5 \mathrm{H}_{2} \mathrm{O}$ is often formed instead of other

$267 \mathrm{Ca}-\mathrm{PO}_{4}$ precipitates when $\mathrm{CO}_{3}$ is present at alkaline $\mathrm{pH}$ values (Wang and Nancollas, 2008), it is

268 likely that $\mathrm{Ca}_{8} \mathrm{H}_{2}\left(\mathrm{PO}_{4}\right)_{6} 5 \mathrm{H} 2 \mathrm{O}$ was formed with $\mathrm{Ca}(\mathrm{OH})_{2}$ on Polonite as follows.

$2706 \mathrm{HPO}_{4}{ }^{2-}+8 \mathrm{Ca}(\mathrm{OH})_{2}+\mathrm{H}_{2} \mathrm{O}=\mathrm{Ca}_{8} \mathrm{H}_{2}\left(\mathrm{PO}_{4}\right)_{6} 5 \mathrm{H}_{2} \mathrm{O}+12 \mathrm{OH}^{-}$

272 Because $\mathrm{CaCO}_{3}$ peaks were reduced after phosphate amendment (Table 1), the following

273 reaction for formation of $\mathrm{Ca}_{8} \mathrm{H}_{2}\left(\mathrm{PO}_{4}\right)_{6} 5 \mathrm{H}_{2} \mathrm{O}$ is also plausible. 
277 Consumption of $\mathrm{Ca}(\mathrm{OH})_{2}$ and $\mathrm{CaCO}_{3}$ resulting from $\mathrm{PO}_{4}$ amendment (reactions 2 and 3) was

278 likely responsible for the lower alkalinity of Polonite-P shown in Figure 1. Dissolution of

$279 \mathrm{CaSiO}_{3}$ could have also provided $\mathrm{Ca}$ for $\mathrm{PO}_{4}$ precipitation. Finally, data in Figure 6 indicated 280 that there was an increase in electrophoretic mobility following phosphate amendment, which 281 implies that $\mathrm{PO}_{4}$ likely formed surface complexes with ionized functional groups ( $c f$. Butkus and 282 Johnson, 2011a).

\subsection{Lead treated Polonite}

287 cases, involves release of Ca. Kietlińska and Renman (2005) reported that calcium leached from 288 Polonite filter columns in amounts of up to almost twice the influent mass of $\mathrm{Ca}$. At $\mathrm{Pb}$ 289 concentrations below $10 \mu$ moles removed from solution with Polonite, Ca was constant and then 290 decreased slightly with increase in $\mathrm{Pb}$ (Figure 3(a)). (Aqueous Ca decreased from ca. $110 \mathrm{mg} / \mathrm{L}$ 291 to $55 \mathrm{mg} / \mathrm{L}$ in this region of $\mathrm{Pb}$ uptake.) The observed decrease in Ca can be attributed to the 292 formation of $\mathrm{CaPb}_{2} \mathrm{O}_{2} \mathrm{H}$, which was observed in the LDI-TOF (m/z of 487, Table 1). Dissolution 293 of $\mathrm{Ca}(\mathrm{OH})_{2}$ and $\mathrm{CaCO}_{3}$ likely contributed to formation $\mathrm{CaPb}_{2} \mathrm{O}_{2} \mathrm{H}$. Increase in $\mathrm{Pb}$ removal above $29410 \mu$ moles resulted in a linear increase in aqueous Ca (Figure 3(b)). 
297 263) on $\mathrm{Pb}$ treated Polonite. Cao et al. (2008) reported that the presence of $\mathrm{Si}, \mathrm{Al}$, and $\mathrm{Ca}$, which

298 are found in Polonite, increase immobilization of $\mathrm{Pb}$ via the formation of $\mathrm{Pb}$-cementitous hydrate

299 products. Rose et al. (2000) reported that $\mathrm{Pb}$ was chemically fixed in $\mathrm{Pb}$-Ca-hydrate via $\mathrm{Pb}-\mathrm{O}-\mathrm{Si}$

300 bonds under similar $\mathrm{pH}$ conditions. These reaction products are most effective at immobilization

301 of $\mathrm{Pb}$ under alkaline $\mathrm{pH}$ conditions, similar to Portland cement (Moon et al., 2013), which is

302 extensible to Polonite immobilization.

Reaction of $\mathrm{Pb}$ with Polonite resulted in the formation of $\mathrm{Pb}$ oxide ions (Table 1), which

305 may have derived from surface complexes and precipitates (Kietlińska and Renman, 2005).

306 Dissolution of $\mathrm{Ca}(\mathrm{OH})_{2}$ followed by precipitation of $\mathrm{Pb}$ is a potential mechanism of $\mathrm{Pb}$ removal

307 and Ca release under alkaline conditions associated with Polonite as reported by Kietlińska and

308 Renman (2005) for other metals. Elzinga and Sparks (2002) reported that Pb appeared to form a

309 combination of coupled mononuclear and polynuclear complexes on $\mathrm{SiO}_{2}$. Lead complexation

310 with amorphous Si increases with pH (Elzinga and Sparks, 2002), which also renders Polonite an

311 effective $\mathrm{Pb}$ sink, since it has relatively high concentrations of $\mathrm{Si}$ and it tends to buffer aqueous

312 systems at alkaline $\mathrm{pH}$ values. However, based on the LDI-TOF data and SEM-EDS images,

313 this mechanism was expected to have a minor influence on overall $\mathrm{Pb}$ immobilization by

314 Polonite. Also, because Polonite contains $4 \% \mathrm{Al}_{2} \mathrm{O}_{3}$ and $2 \% \mathrm{Fe}_{2} \mathrm{O}_{3}$ (Renman et al., 2009), $\mathrm{Pb}$

315 could have formed inner sphere complexes with Al oxides (Chisholm-Brause, 1990) and Fe

316 oxides (Roe et al., 1991) on Polonite. Lead carbonate species were not observed in the LDI-TOF

317 data. Based on this observation and differences in electrophorectic mobility between $\mathrm{Pb}$ treated

318 Polonite and $\mathrm{PbCO}_{3}$, precipitates of $\mathrm{Pb}$ and $\mathrm{CO}_{3}$ were considered negligible. 


\subsection{Lead treated Polonite-P}

Mavropoulous et al. (2002) reported that uptake of $\mathrm{Pb}$ and release of Ca could be used as

323 a means of discerning the mechanism of lead uptake on HA. A similar approach was used here

324 because Polonite has a substantial quantity of $\mathrm{Ca}$ and Polonite-P likely contains precipitates of

$325 \mathrm{Ca}$ and $\mathrm{PO}_{4}$. Using this approach, $\mathrm{Pb}$ removal by Polonite-P appeared to occur by several

326 mechanisms as indicated by the changes in Polonite-P slope in Figure 4(a). At values below $c a$.

$32710 \mu$ mole $\mathrm{Pb}$ removed from the aqueous phase, $\mathrm{Ca}$ increases gradually with $\mathrm{Pb}$ removal. The

328 slope of the line increases substantially above $c a .10 \mu$ mole Pb removed. The LDI-TOF data

329 was collected with $\mathrm{Pb}$ treated Polonite-P samples with an average final mass ratio of $3.97 \mathrm{mg}$

$330 \mathrm{~Pb} / \mathrm{g}$ Polonite-P. This point is located in Figure 4(a) where the slope has transitioned into the

331 linear region (77 $\mu$ moles $\mathrm{Pb}$ removed from solution). Consequently, the LDI-TOF data should

332 represent $\mathrm{Pb}$ species derived from most mechanisms of $\mathrm{Pb}$ removal. Because LDI-TOF

333 identified PbAlSi on the surface of $\mathrm{Pb}$ treated Polonite- $\mathrm{P}(\mathrm{m} / \mathrm{z}$ of 263 , Table 1$), \mathrm{Pb}$ was

334 chemically fixed in Ca-Si-hydrate as discussed above. The LDI-TOF data (Table 1) also

335 identified the presence of $\mathrm{Pb}$ and $\mathrm{PO}_{4}$ ions and precipitates including $\mathrm{Pb}_{2} \mathrm{PO}_{4}, \mathrm{~Pb}_{3} \mathrm{O}\left(\mathrm{PO}_{4}\right)$, and

$336 \mathrm{~Pb}_{4} \mathrm{O}\left(\mathrm{PO}_{4}\right)_{2}$ on the surface of $\mathrm{Pb}$ treated Polonite-P. Species on the surface of the $\mathrm{Pb}-\mathrm{PO}_{4}$ control

337 included $\mathrm{Pb}_{2} \mathrm{PO}_{4}$ and $\mathrm{Pb}_{3} \mathrm{O}\left(\mathrm{PO}_{4}\right)$. Using X-ray Diffraction (XRD), Butkus and Johnson (2011a)

338 reported that a similar control material was comprised of pyromorphite $\left(\mathrm{Pb}_{5}\left(\mathrm{PO}_{4}\right)_{3}(\mathrm{OH})\right)$.

339 Pyromorphite could not be confirmed for any samples with LDI-TOF, because of noise in the

$340 \mathrm{~m} / \mathrm{z}$ range of 1337 . However, $\mathrm{Pb}_{4} \mathrm{O}\left(\mathrm{PO}_{4}\right)_{2}$ was not observed on the control. This implies that

341 differences in the form of $\mathrm{Pb}-\mathrm{PO}_{4}$ species existed between the control and Polonite-P. (XRD was 
342 unable to reveal $\mathrm{Pb}-\mathrm{PO}_{4}$ species on Polonite and Polonite-P due to the relatively low

343 concentrations of these compounds in the complex Polonite matrices; data not shown).

344 Transition from $\mathrm{Pb}_{4} \mathrm{O}\left(\mathrm{PO}_{4}\right)_{2}$ to $\mathrm{Pb}_{5}\left(\mathrm{PO}_{4}\right)_{3}(\mathrm{OH})$, on $\mathrm{Pb}$ treated Polonite- $\mathrm{P}$, would be expected at

$345 \mathrm{pH}$ below 9.5 (Michalowska-Kaczmarczyk and Michalowski, 2014). The control and Pb treated

346 Polonite-P both contained $\mathrm{Pb}$ oxides at $\mathrm{m} / \mathrm{z}$ of 430 and 448 . It is uncertain if these oxides were

347 derived from a species comprised of $\mathrm{Pb}$ and $\mathrm{PO}_{4}$ prior to exposure to $\mathrm{LDI}$. It is also uncertain if

$348 \mathrm{~Pb}_{2} \mathrm{PO}_{4}$ and $\mathrm{Pb}_{3} \mathrm{O}\left(\mathrm{PO}_{4}\right)$ were formed from $\mathrm{Pb}-\mathrm{PO}_{4}$ precipitates during $\mathrm{LDI}$ or if it they were

349 derived from surface complexes during LDI. The observed increase in electrophoretic mobility

350 of $\mathrm{Pb}$ treated Polonite-P (Figure 6) offers limited support for the latter. Dissolution of

$351 \mathrm{Ca}_{8} \mathrm{H}_{2}\left(\mathrm{PO}_{4}\right)_{6} 5 \mathrm{H}_{2} \mathrm{O}$ followed by formation of $\mathrm{Pb}_{4} \mathrm{O}\left(\mathrm{PO}_{4}\right)_{2}$ and $\mathrm{Pb}_{2} \mathrm{PO}_{4}$ (if it existed prior to LDI)

352 are proposed mechanisms of $\mathrm{Pb}$ removal by Polonite- $\mathrm{P}$ as follows.

$354 \mathrm{Ca}_{8} \mathrm{H}_{2}\left(\mathrm{PO}_{4}\right)_{6} 5 \mathrm{H}_{2} \mathrm{O}+12 \mathrm{~Pb}^{2+}=3 \mathrm{~Pb}_{4} \mathrm{O}\left(\mathrm{PO}_{4}\right)_{2}+8 \mathrm{Ca}^{2+}+8 \mathrm{H}^{+}+2 \mathrm{H}_{2} \mathrm{O}$

$\mathrm{Ca}_{8} \mathrm{H}_{2}\left(\mathrm{PO}_{4}\right)_{6} 5 \mathrm{H}_{2} \mathrm{O}+12 \mathrm{~Pb}^{2+}=6 \mathrm{~Pb}_{2} \mathrm{PO}_{4}^{+}+8 \mathrm{Ca}^{2+}+2 \mathrm{H}^{+}+5 \mathrm{H}_{2} \mathrm{O}$

358 The ratio of $\mathrm{Ca}$ release to $\mathrm{Pb}$ removal is 0.66 in both cases, which corresponds to the slope of the 359 data for $\mathrm{Pb}$ treated Polonite-P shown in Figure 4(b). The ratio of Ca release to $\mathrm{Pb}$ removal for

$360 \mathrm{Ca}_{8} \mathrm{H}_{2}\left(\mathrm{PO}_{4}\right)_{6} \cdot 5 \mathrm{H}_{2} \mathrm{O}$ and $\mathrm{Pb}$ forming $\mathrm{Pb}_{5}\left(\mathrm{PO}_{4}\right)_{3}(\mathrm{OH})$ is 0.8 . The ratio of Ca release to $\mathrm{Pb}$ removal

361 for $\mathrm{Ca}_{8} \mathrm{H}_{2}\left(\mathrm{PO}_{4}\right)_{6} 5 \mathrm{H}_{2} \mathrm{O}$ and $\mathrm{Pb}$ forming $\mathrm{Pb}_{3} \mathrm{O}\left(\mathrm{PO}_{4}\right)$ is 0.44 . These ratios are not consistent with

362 the data in Figure 4(b). Cao et al. (2004) reported a slope of 0.92 for Ca release, as a function of 
$363 \mathrm{~Pb}$ removal, when using $\mathrm{PO}_{4}$ rock as a substrate. Mavropoulous et al. (2002) reported that the

364 molar ratio of $\mathrm{Ca}$ release to $\mathrm{Pb}$ removal decreased from 0.92 to 0.65 as a function of initial

365 aqueous $\mathrm{Pb}$ concentration (from $581 \mathrm{mg} \mathrm{Pb} / \mathrm{L}$ to $1770 \mathrm{mg} \mathrm{Pb} / \mathrm{L}$ ) on $\mathrm{HA}$, which they attributed to

366 surface immobilization. The release of $\mathrm{H}^{+}$, in reactions (4) and (5), suggests that $\mathrm{pH}$ should

367 decrease with increase in $\mathrm{Pb}$ removal and this was observed at $\mathrm{pH}<10.3$ in the Polonite- $\mathrm{P}$

368 sorption edge shown in Figure 2. Further, the $\mathrm{pH}$ point $(5.4,10)$ where final $\mathrm{pH}$ begins to

369 decrease substantially in the Polonite-P data (Figure 1) corresponds to the same Pb removal (77

$370 \mu$ moles of $\mathrm{Pb}$ removed from the aqueous phase in Figure 4(a)), where the Ca released data begins

371 to increase linearly at a slope of 0.66 .

372

373 Surface complexation of $\mathrm{Pb}$ with $\mathrm{HA}$ surface functional groups could be modeled with

374 ion exchange reactions including the following (Mavropoulos et al. (2002).

375

376

$$
\equiv \mathrm{CaOH}+\mathrm{Pb}^{2+} \Leftrightarrow \equiv \mathrm{CaOPb}^{+}+\mathrm{H}^{+}
$$

378 Similar processes are plausible for the surface of Polonite-P based on the observed increase in 379 electrophoretic mobility (Figure 6) and the Pb oxides observed in the LDI-TOF data (Table 1). 380 Lead surface complexes with Al oxides (Chisholm-Brause, 1990) and Fe oxides (Roe et al., 381 1991) are also possible as discussed above. Species comprised of $\mathrm{Pb}$ and $\mathrm{CO}_{3}$ and $\mathrm{Pb}$ and $\mathrm{OH}$ 382 will not form in appreciable concentrations at equilibrium when $\mathrm{PO}_{4}$ is available, due to lower 383 solubility limits (Nriagu, 1974; Traina and Laperche, 1999). Because of this and differences in 384 electrophoretic mobility discussed above, $\mathrm{PbCO}_{3}$ and $\mathrm{Pb}(\mathrm{OH})_{2}$, two more soluble forms of $\mathrm{Pb}$ 
385 solids, were not expected to be present in an appreciable concentration on the surface of

386 Polonite-P.

387

\subsection{Potential use of Polonite-P as a stabilization agent}

The accepted practice of using $\mathrm{HA}$ for $\mathrm{Pb}$ stabilization under low to neutral $\mathrm{pH}$ conditions

390 requires substantial incubation times and can lead to inadvertent transport of $\mathrm{Pb}$ complexes

391 (Butkus and Johnson, 2011a and 2011b). Polonite-P could be a suitable replacement for HA and

392 other $\mathrm{PO}_{4}$ sources, which require low $\mathrm{pH}$ as a stabilization amendment for the following reasons:

393 - it is an alkaline material, which will increase soil $\mathrm{pH}$ and provide buffering in unbuffered $394 \quad$ soils;

395 - colloidal $\mathrm{Pb}$ species tend to be less mobile under alkaline $\mathrm{pH}$ conditions (Chen et al., 396 2002; Butkus and Johnson, 2011b);

397 it promotes formation of $\mathrm{Pb}-\mathrm{PO}_{4}$ precipitates (Nriagu, 1974) and $\mathrm{Pb}$-cementitous hydrate 398 products (Cao et al., 2008), which are desirable forms of stabilized lead;

399 - Polonite has been evaluated and recommended for further study as a multicomponent $400 \quad$ fertilizer ( $c f$. Cucarella et al, 2008); and

401 - $\mathrm{PO}_{4}$ amendment could be accomplished by reusing Polonite that was first used to capture 402 $\mathrm{PO}_{4}$ in wastewater applications (Renman and Renman, 2010).

403 Field studies could further elucidate the efficacy of Polonite-P as a Pb stabilization agent.

\section{5. Conclusions}


407 from aqueous systems. Both Polonite and Polonite-P were capable of forming $\mathrm{Pb}$-cementitous

408 hydrate products, which are desirable forms of stabilized $\mathrm{Pb}$. However, the results suggest that

$409 \mathrm{PO}_{4}$, on Polonite-P, could also be released to form desirable $\mathrm{Pb}_{-} \mathrm{PO}_{4}$ precipitates that are known

410 to have low solubility. For these reasons, Polonite-P should be further evaluated as a

411 replacement for current $\mathrm{PO}_{4}$ sources as a $\mathrm{Pb}$ stabilization agent. 


\section{Acknowledgments}

413

414 The technical assistance of Mr. Anand Shetty, Mark Lennox, and Taylor Pearce, Department of

415 Geography and Environmental Engineering, United States Military Academy is greatly

416 appreciated. The technical assistance of Christina Tricomi, Department of Chemistry and Life

417 Science, United States Military Academy is greatly appreciated. This project was supported by a

418 grant from the US Army Research Laboratory. Although the research presented in this paper has

419 been undertaken by personnel employed by US Military Academy, it does not necessarily reflect

420 the views of the Academy or the US Army.

421 
423 Butkus, M.A., Johnson, M.C., 2011a. Reevaluation of phosphate as a means of retarding lead

Butkus, M.A., Johnson, M.C., 2011b. Influence of Phosphate on the Transport Properties of Lead in Sand, J. Haz. Mat. 185 (1), 275-280.

Cao, X., Dermatas, D., Xu, X., Shen, G., 2008. Immobilization of lead in shooting range soils by means of cement, quicklime, and phosphate amendments, Env. Sci. Pollut. Res. 15 (2), 120-127.

Cao, X., Ma, L.Q., Rhue, D.R., Appel, C.S., 2004. Mechanisms of lead, copper, and zinc retention by phosphate rock, Environ. Pollut. 131 (3), 435-444.

Chen, M., Daroub, S.H., Ma, L.Q., Harris, W.G., Cao, X., 2002. Characterization of lead in soils of a rifle/pistol shooting range in central Florida, USA, Soil Sediment Contam. 11 (1), 1-17.

Chrysochoou, M., Dermatas, D., Grubb, D.G., 2007. Phosphate application to firing range soils for $\mathrm{Pb}$ immobilization: the unclear role of phosphate, J. Haz. Mat. 144 (1-2), 1-14.

Cucarella, V., Zaleski, T., Mazurek, R., Renman, G. 2008. Effect of reactive substrates used for the removal of phosphorus from wastewater on the fertility of acid soils, Bioresource Technol. 99 (10), 4308-4314.

Cucarella, V., Renman, G., 2009. Phosphorus sorption capacity of filter materials used for onsite wastewater treatment determined in batch experiments-a comparative study, J. Environ. Qual. 38 (2), 381-392.

Dyson, P. J., Hearley, A. K., Johnson, B. F., Langridge-Smith, P. R., McIndoe, J. S., 2004. Analysis of low oxidation state transition metal clusters by laser desorption/ionization time-offlight mass spectrometry. Inorg. Chem. 43 (16), 4962-4973.

Elzinga, E. J., Sparks, D. L., 2002. X-ray absorption spectroscopy study of the effects of pH and ionic strength on $\mathrm{Pb}$ (II) sorption to amorphous silica, Environ. Sci. Technol, 36 (20), 4352-4357.

Eveborn, D., Gustafsson, J. P., Hesterberg, D., Hillier, S., 2009. XANES speciation of P in environmental samples: An assessment of filter media for on-site wastewater treatment, Environ. Sci. Technol, 43 (17), 6515-6521.

Fernández-Caliani, J. C., Barba-Brioso, C., Pérez-López, R., 2008. Long-term interaction of wollastonite with acid mine water and effects on arsenic and metal removal, Appl. Geochem. 23 (5), 1288-1298.

Hashimoto, Y., Sato, T., 2007. Removal of aqueous lead by poorly-crystalline hydroxyapaties. Chemosphere 69 (11), 1775-1782. 
Herrmann, I., Nordqvist, K., Hedström, A., Viklander, M., 2014. Effect of temperature on the performance of laboratory-scale phosphorus-removing filter beds in on-site wastewater treatment, Chemosphere, 117, 360-366.

Jørgensen, S.S., Willems, M., 1987. The fate of lead in soils: the transformation of lead pellets in shooting-range soils. Ambio. 16 (1), 11-15.

Kietlińska, A., Renman, G., 2005. An evaluation of reactive filter media for treating landfill leachate, Chemosphere 61 (7), 933-940.

Kilgour, D.W., Moseley, R.B., Barnett, M.O., Savage, K.S., Jardine, P.M., 2008. Potential Negative Consequences of Adding Phosphorous-Based Fertilizers to Immobilize Lead in Soil. J. Environ. Qual. 37 (5), 1733-1740.

Mavropoulos, E., Rossi, A.M., Costa, A.M., Perez, C.A.C., Moreira, J.C., Saldanha, M., 2002. Studies on the mechanisms of lead immobilization by hydroxyapatite, Environ. Sci. Technol. 36 (7), 1625-1629.

Michałowska-Kaczmarczyk, A. M., Michałowski, T., 2014. Evaluation of Transition Points between Different Solid Phases in Aqueous Media, J. Analytical Sciences, Methods and Instrumentation, 4 (03), 87-94.

Moon, D.H., Park, J.W., Chang, Y.Y., Ok, Y.S., Lee, S.S., Ahmad, M., Koutsospyros, K., Park, J.H., Back, K. 2013. Immobilization of lead in contaminated firing range soil using biochar. Environ. Sci. Pollut. Res. 20 (12), 8464-8471.

Park, J. H., Bolan, N., Megharaj, M., Naidu, R., 2011. Comparative value of phosphate sources on the immobilization of lead, and leaching of lead and phosphorus in lead contaminated soils, Sci. Total Environ. 409 (4), 853-860.

Rose, J., Moulin, I., Hazemann, J.L., Masion, A., Bertsch, P.L., Bottero, J.Y., Mosnier, F., Haehnel, C., 2000. X-ray absorption spectroscopy study of immobilization processes for heavy metals in calcium silicate hydrates: 1. case of lead, Langmuir 16 (25), 9900-9906.

Renman, A., Renman, G., Gustafsson, J.P., Hylander, L., 2009. Metal removal by bed filter materials used in domestic wastewater treatment. J. Haz. Mat. 166 (2-3), 734-739.

Renman, A., Renman, G., 2010. Long-term phosphate removal by the calcium-silicate material Polonite in wastewater filtration systems. Chemosphere 79 (6), 659-664.

Sugiyama, S., Ichii, T., Hayashi, H., Tomida, T., 2002. Lead immobilization by non-apatite-type calcium phosphates in aqueous solutions. Inorg. Chem. Comm. 5 (2), 156-158.

Suzuki, T., Ishigaki, K., Miyake M., 1984. Synthetic hydroxyapatites as inorganic cation exchangers Part 3. Exchange characteristics of lead ions $\left(\mathrm{Pb}^{2+}\right)$. J. Chem. Soc. Faraday Trans. 1 80 (11), 3157-3165. 
514 Traina, S.J., Laperche, V., 1999. Contaminant bioavailability in soils, sediments, and aquatic 515 environments, Proc. Natl. Acad. Sci. USA 96 (7), 3365-3371. spectra for speciation of inorganic salts with static secondary ion mass spectrometry, Analytical chemistry, 76 (9), 2609-2617.

Wang, L., Nancollas, G. H., 2008. Calcium orthophosphates: crystallization and dissolution, Chem. Rev. 108 (11), 4628-4669.

Wouters, L. C., Van Grieken, R. E., Linton, R. W., Bauer, C. F., 1988. Discrimination between coprecipitated and adsorbed lead on individual calcite particles using laser microprobe mass analysis, Anal. Chem. 60 (20), 2218-2220.

530

531

532 


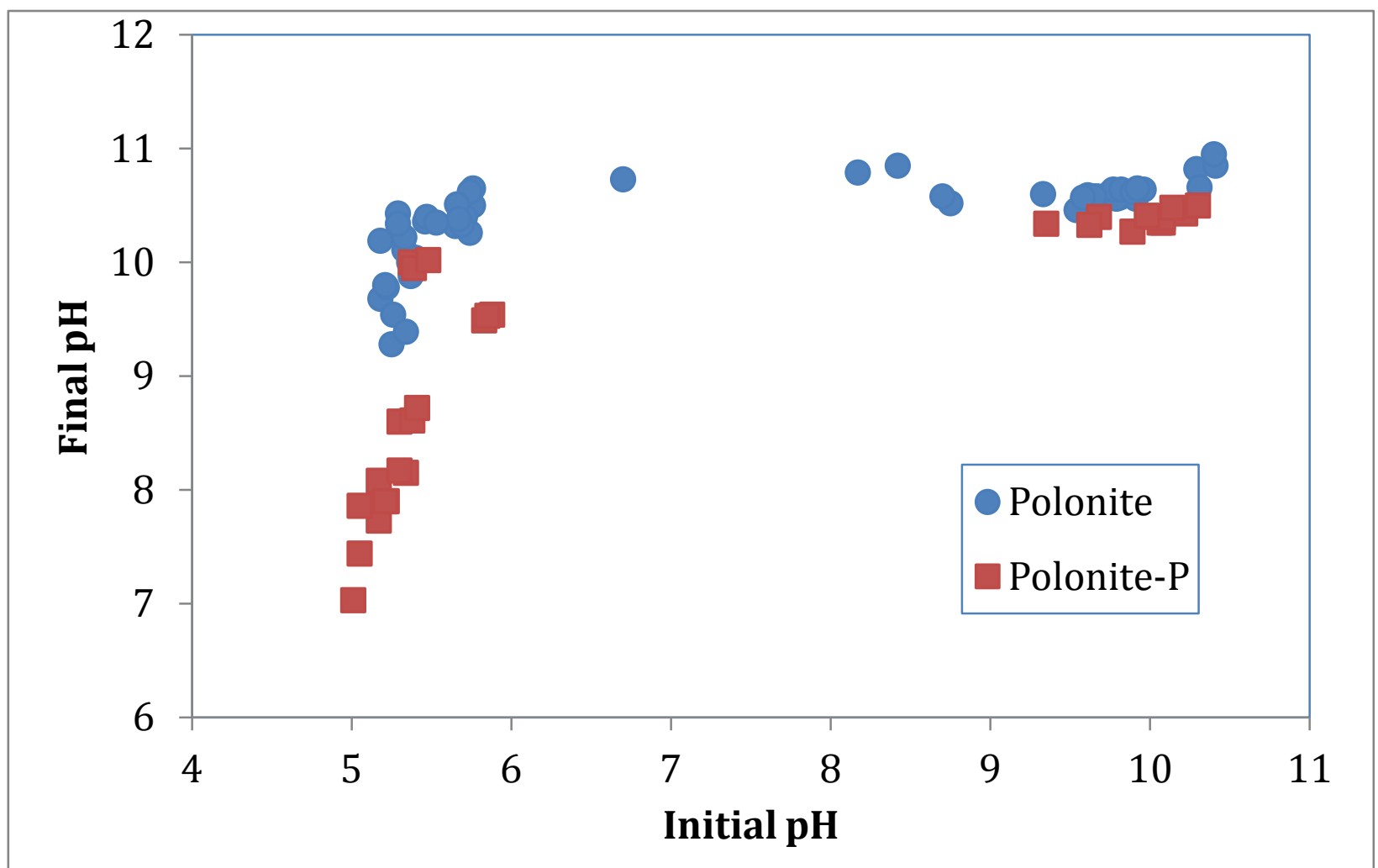

535 Figure 1. Trends in $\mathbf{p H}$ at the start and completion of sorption experiments. Initial pH was

536 measured approximately 20 minutes after $\mathrm{PbNO}_{3}$ solutions were combined with Polonite 537 and final pH was measured after a 48 hour incubation period. 


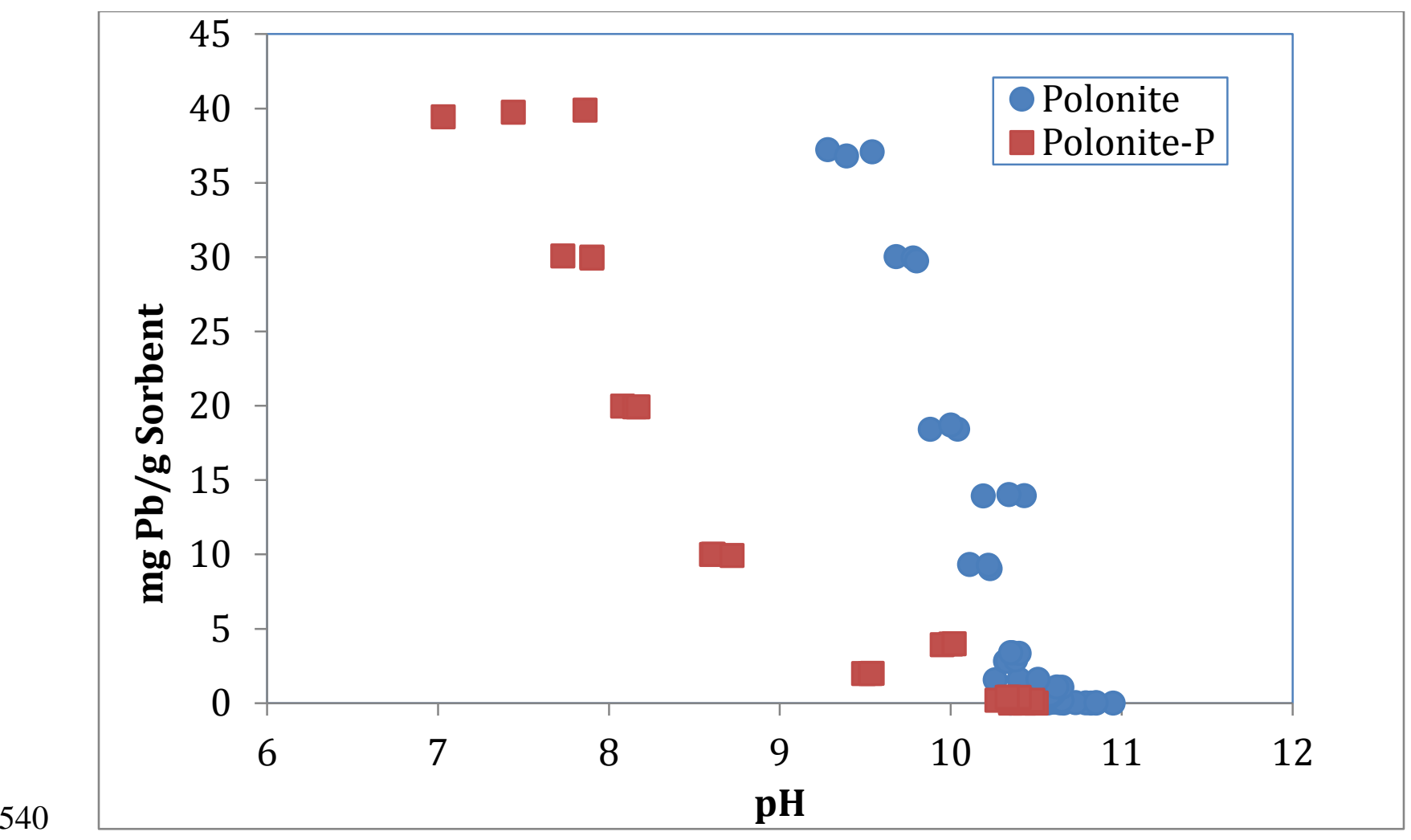

541 Figure 2. Lead sorption edges for suspensions that were formed by combining $20 \%$, by

542 weight, of Polonite or Polonite-P with various concentrations of $\mathrm{Pb}$. Suspensions were

543 incubated under constant shaking, 200 RPM, at $25^{\circ} \mathrm{C}$ for 48 hours.

544

545 

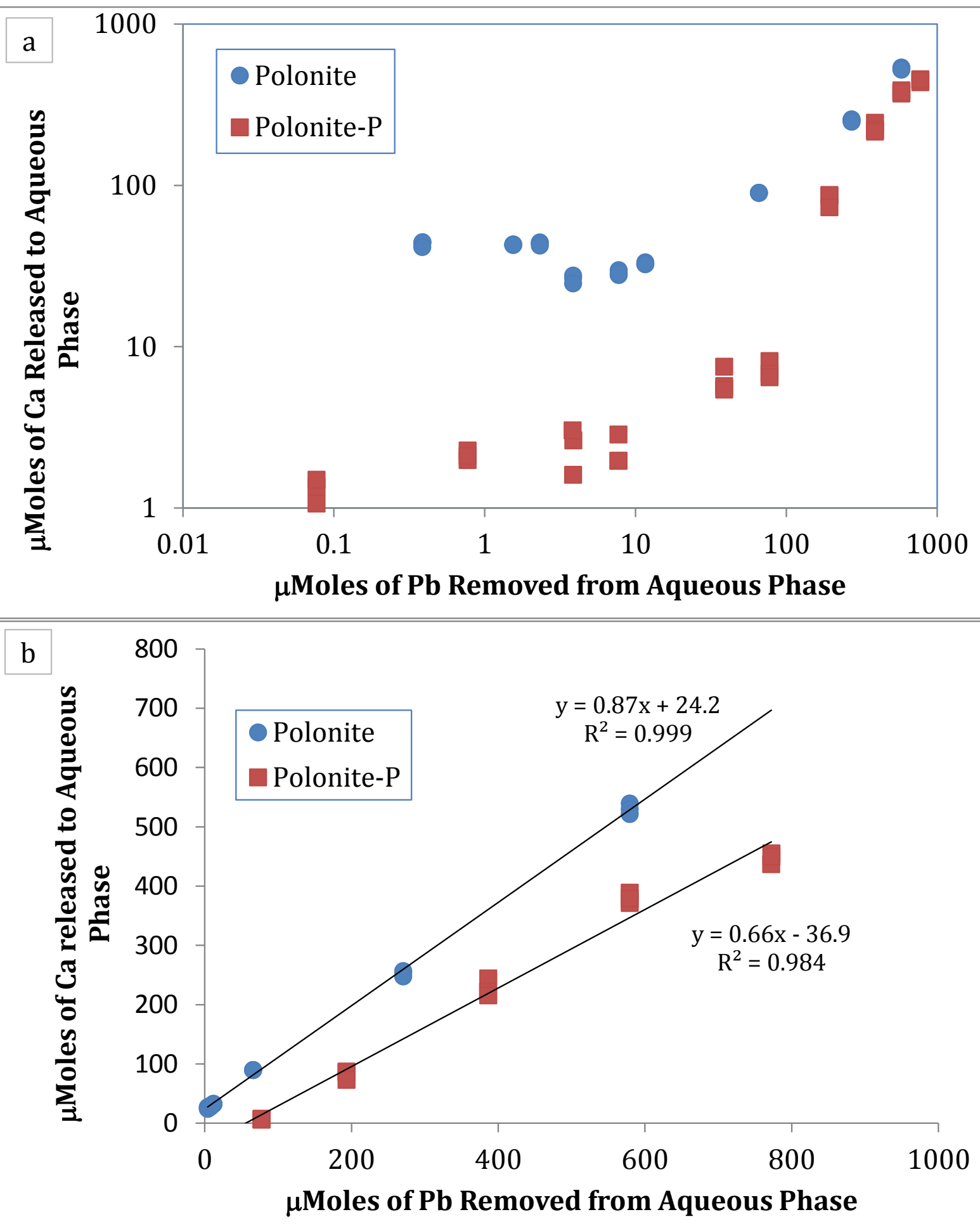

547 Figure 3. (a) Calcium release to solution as function of $\mathrm{Pb}$ removal. $\mathrm{Pb}$ and $\mathrm{Ca}$ were

548 measured following a $\mathbf{4 8}$ hour incubation period. (b) Linear region of Ca release to 549 solution as function of $\mathrm{Pb}$ removal. 


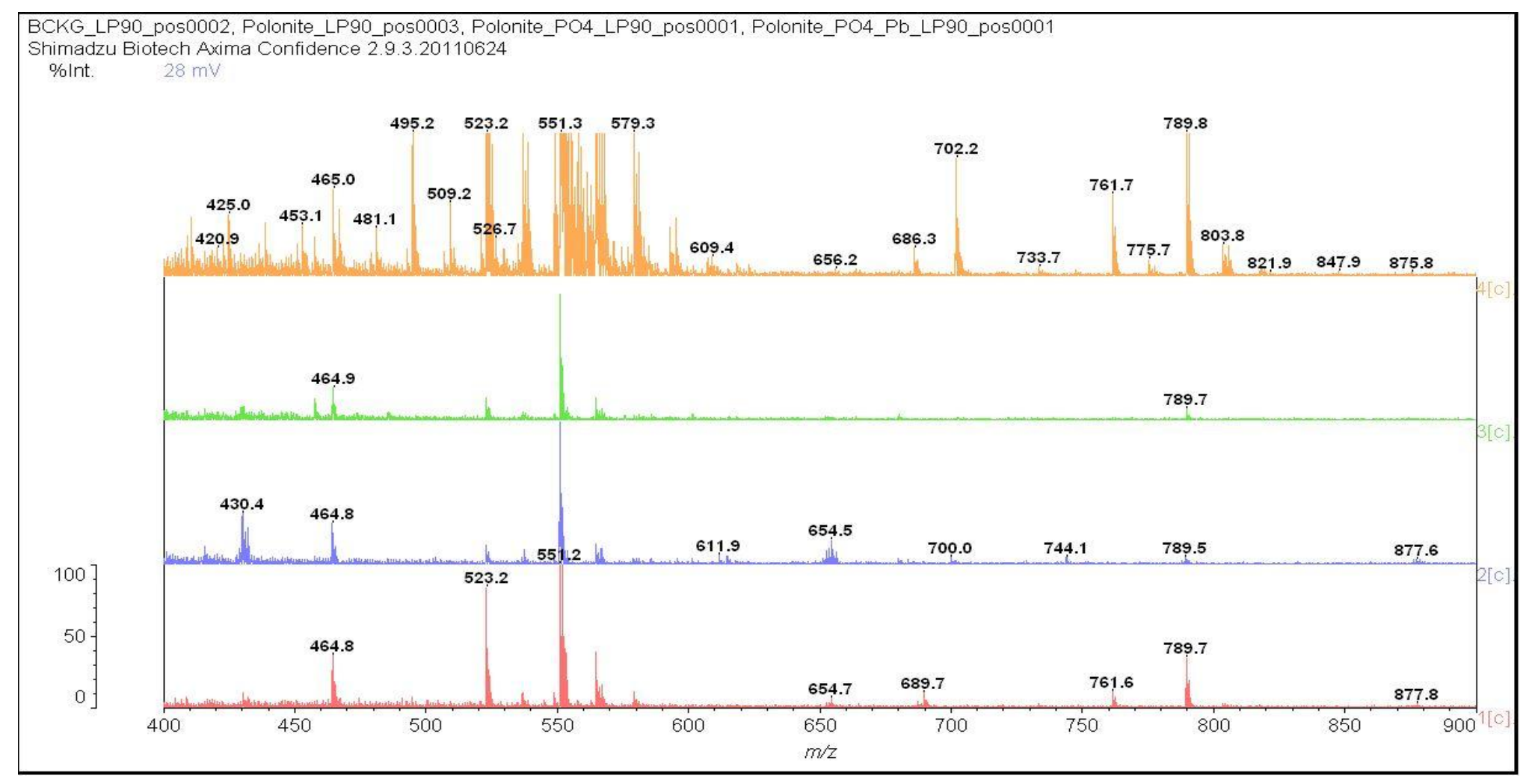

Figure 4. Comparison LDI of spectra: stainless steel background (red); Polonite (blue); Polonite-P (green); and, Pb treated

Polonite-P (orange). Spectra are normalized to the Polonite spectram. Spectra are an average of 3000 laser shots. 


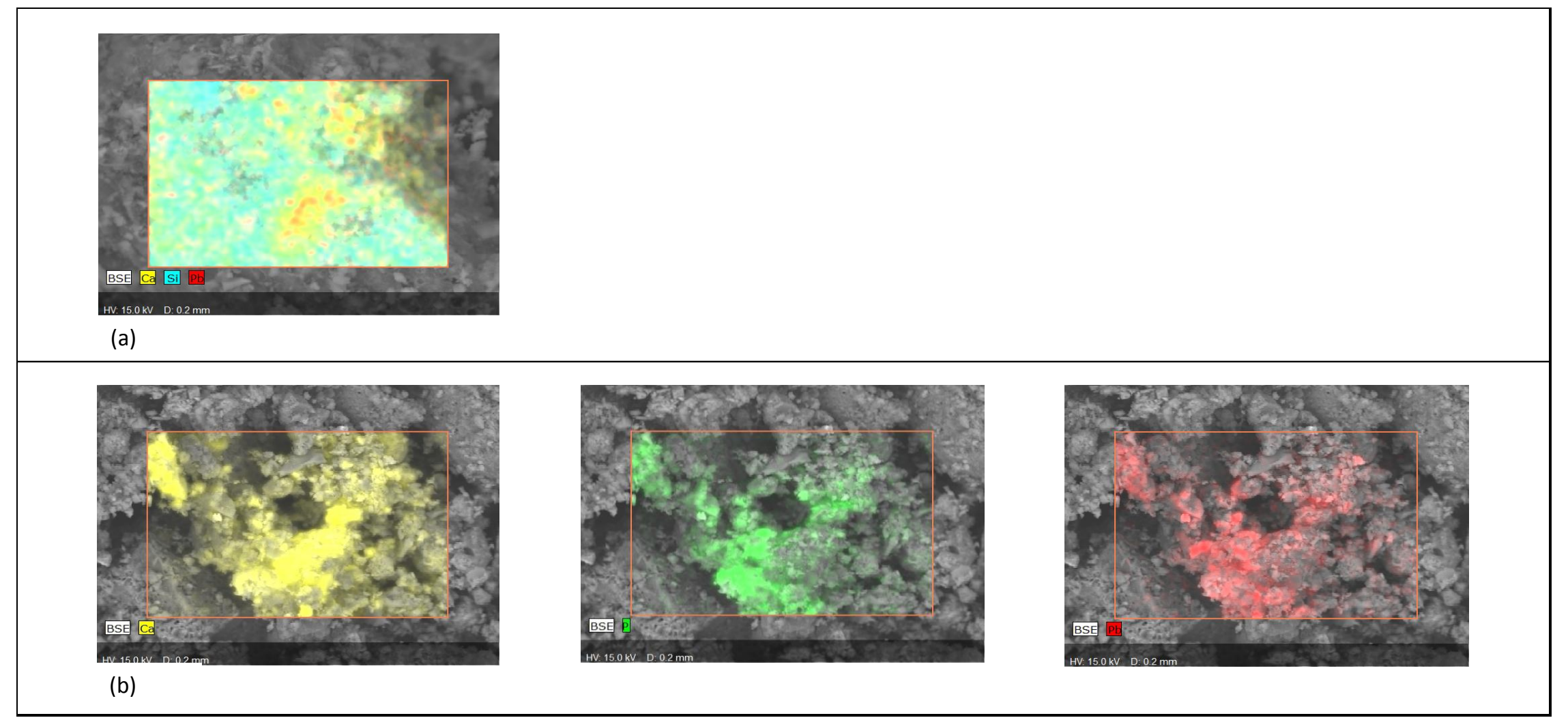

Figure 5. (a) SEM-EDS image of Polonite treated with Pb: Ca (yellow), Si (blue), and Pb (red) are mapped on the surface.

This image was detected at an 8000x magnification of the sample. (b) SEM-EDS images of Polonite-P treated with Pb: Ca (yellow), $\mathrm{P}$ (green), and $\mathrm{Pb}$ (red) are mapped at the same location on the surface. This image was detected at a 2000x magnification of the sample. 


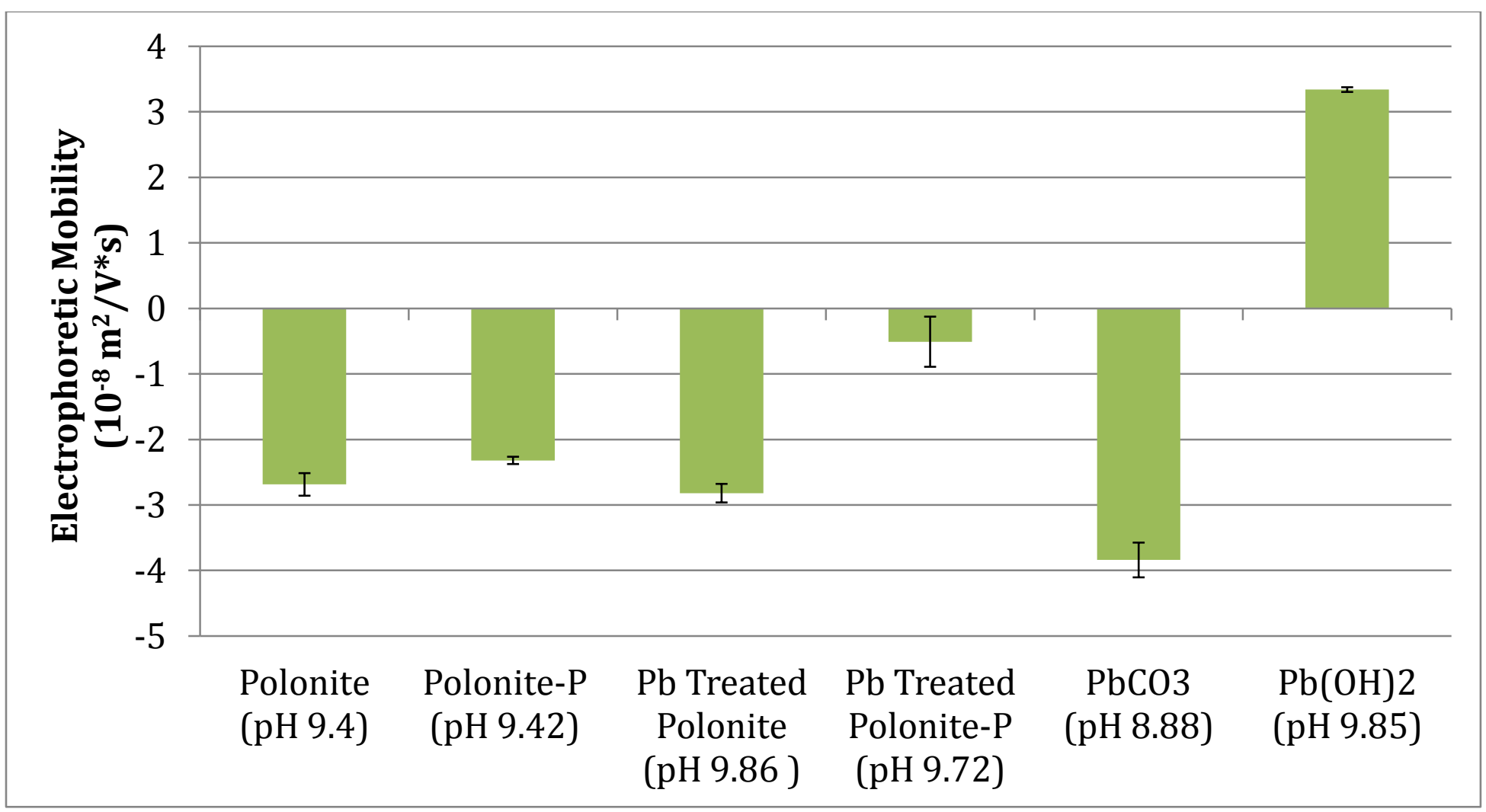

Figure 6. Electrophoretic mobility of suspensions at $25^{\circ} \mathrm{C}$ in $1 \mathrm{~m} M \mathrm{KNO}_{3}$. Error bars represent one standard deviation. 
Table 1. Proposed species observed with laser desorption ionization mass spectrometry with time of flight detection (LDI-TOF). The extent to which an ion was observed was defined as follows: small peak (sm) being a minimum of $3 x$ the intensity of the background noise signal and average peak $(X)$ being a minimum of $10 x$ the intensity of the background noise signal.

\begin{tabular}{|c|c|c|c|c|c|c|}
\hline $\begin{array}{l}\text { Proposed } \\
\text { Positive Ion }\end{array}$ & Mass & $\begin{array}{c}\text { Lead } \\
\text { Phosphate } \\
\text { control }\end{array}$ & $\begin{array}{c}\text { Plain } \\
\text { Polonite }\end{array}$ & $\begin{array}{l}\text { Amended } \\
\text { Polonite }\end{array}$ & $\begin{array}{c}\text { Polonite } \\
\text { Treated } \\
\text { with } \\
\text { Pb }^{\mathbf{a}}\end{array}$ & $\begin{array}{c}\text { Polonite-P } \\
\text { Treated } \\
\text { with } \mathbf{P b}^{\mathbf{b}}\end{array}$ \\
\hline $\mathrm{SiO}_{2} \mathrm{H}_{2} \mathrm{O}$ & 78 & & & $X$ & $\mathrm{X}$ & $\mathrm{X}$ \\
\hline $\mathrm{HPO}_{4}$ & 96 & $\mathrm{sm}$ & $X$ & $\mathrm{X}$ & $X$ & $\mathrm{X}$ \\
\hline $\mathrm{AlSiO}_{3}$ & 103 & & & $\mathrm{X}$ & $\mathrm{X}$ & $\mathrm{X}$ \\
\hline $\mathrm{Ca}_{2} \mathrm{O}_{2}$ & 112 & & $\mathrm{X}$ & $\mathrm{X}$ & $\mathrm{X}$ & $\mathrm{X}$ \\
\hline $\mathrm{Ca}_{2} \mathrm{O}_{3}$ & 128 & $\mathrm{sm}$ & $X$ & $X$ & $\mathrm{X}$ & $X$ \\
\hline $\mathrm{Ca}_{2} \mathrm{O}_{3} \mathrm{Mg}$ & 152 & & $X$ & $X$ & $X$ & $X$ \\
\hline $\mathrm{K}_{2} \mathrm{PO}_{3}$ & 157 & & & $\mathrm{X}$ & $\mathrm{X}$ & $\mathrm{sm}$ \\
\hline $\mathrm{Pb}$ & 208 & $\mathrm{X}$ & & & $\mathrm{X}$ & $\mathrm{X}$ \\
\hline $\mathrm{PbNaO}$ & 247 & $\mathrm{X}$ & & & & \\
\hline $\mathrm{PbAlSi}$ & 263 & & & & $\mathrm{X}$ & $\mathrm{X}$ \\
\hline $\mathrm{PbPO}_{3}$ & 287 & $\mathrm{X}$ & & & & \\
\hline $\mathrm{Pb}_{2}$ & 415 & $\mathrm{X}$ & & & $\mathrm{X}$ & $\mathrm{X}$ \\
\hline $\mathrm{Pb}_{2} \mathrm{O}$ & 430 & $\mathrm{X}$ & & & $\mathrm{X}$ & $\mathrm{X}$ \\
\hline $\mathrm{Pb}_{2} \mathrm{OOH}$ & 448 & $\mathrm{X}$ & & & $\mathrm{X}$ & $\mathrm{sm}$ \\
\hline $\mathrm{CaPb}_{2} \mathrm{O}_{2} \mathrm{H}$ & 487 & & & & $\mathrm{X}$ & \\
\hline $\mathrm{Pb}_{2} \mathrm{PO}_{4}$ & 509 & $\mathrm{X}$ & & & & $\mathrm{X}$ \\
\hline $\mathrm{Pb}_{3}$ & 622 & $\mathrm{sm}$ & & & $\mathrm{sm}$ & $\mathrm{X}$ \\
\hline $\mathrm{Pb}_{3} \mathrm{O}_{2}$ & 655 & $\mathrm{X}$ & & & $\mathrm{X}$ & $\mathrm{sm}^{\mathrm{c}}$ \\
\hline $\mathrm{Pb}_{3} \mathrm{O}_{3}$ & 671 & & & & $\mathrm{X}$ & \\
\hline $\mathrm{Pb}_{3} \mathrm{O}_{4} \mathrm{Mg}$ & 710 & & & & $\mathrm{X}$ & \\
\hline $\mathrm{Pb}_{3} \mathrm{O}\left(\mathrm{PO}_{4}\right)$ & 733 & $\mathrm{X}^{\mathrm{c}}$ & & & & $\mathrm{X}^{\mathrm{c}}$ \\
\hline $\mathrm{Pb}_{4}$ & 830 & $\mathrm{sm}$ & & & & $\mathrm{X}$ \\
\hline $\mathrm{Pb}_{4} \mathrm{O}_{3}$ & 878 & & & & $\mathrm{X}$ & \\
\hline $\mathrm{Pb}_{4} \mathrm{O}_{3} \mathrm{OH}$ & 895 & & & & $X$ & \\
\hline $\mathrm{Pb}_{4} \mathrm{O}\left(\mathrm{PO}_{4}\right)_{2}$ & 1036 & & & & & $\mathrm{X}^{\mathrm{c}}$ \\
\hline $\begin{array}{l}\text { Proposed } \\
\text { Negative } \\
\text { Ion }\end{array}$ & Mass & $\begin{array}{c}\text { Lead } \\
\text { Phosphate } \\
\text { control }\end{array}$ & $\begin{array}{c}\text { Plain } \\
\text { Polonite }\end{array}$ & $\begin{array}{l}\text { Amended } \\
\text { Polonite }\end{array}$ & $\begin{array}{c}\text { Polonite } \\
\text { Treated } \\
\text { with } \\
\text { Pb }^{\mathbf{a}}\end{array}$ & $\begin{array}{c}\text { Polonite-P } \\
\text { Treated } \\
\text { with } \mathbf{P b}^{\mathbf{b}}\end{array}$ \\
\hline $\mathrm{CaCO}_{3}$ & 100 & & $\mathrm{X}$ & $\mathrm{sm}$ & $\mathrm{sm}$ & $\mathrm{X}$ \\
\hline $\mathrm{Pb}_{3} \mathrm{O}_{2}(\mathrm{OH})_{2}$ & 688 & & & & $X$ & \\
\hline
\end{tabular}

Table 1. Footnotes

a. $19.6 \mathrm{mg} \mathrm{Pb} / \mathrm{g}$ Polonite

b. $3.97 \mathrm{mg} \mathrm{Pb} / \mathrm{g}$ Polonite-P

c. These species were observed at higher laser power. 